\title{
Immunogenicity of Bone Graft Using Xenograft Freeze-Dried Cortical Bovine, Allograft Freeze-Dried Cortical New Zealand White Rabbit, Xenograft Hydroxyapatite Bovine, And Xenograft Demineralized Bone Matrix Bovine In Bone Defect Of Femoral Diaphysis White Rabbit Experimental Study In Vivo
}

Ferdiansyah, Dwikora Novembri Utomo, Heri Suroto, and Imelda Lumban Gaol

Corresponding Author:

Ferdiansyah

Received: 03 October 2017

Accepted: 10 October 2017

Published: 29 November 2017

Publishing services provided by Knowledge E

(a) Ferdiansyah et al. This article is distributed under the terms of the Creative

which permits unrestricted use and redistribution provided that the original author and source are credited

Selection and Peer-review under the responsibility of the VMIC Conference Committee.

\section{Abstract}

Introduction Bone defect remains a big challenge for orthopedic surgeon. Bone grafting nowadays become the second common transplantation after blood transfusion. Autogenous bone graft is the gold standard in treatment of bone defect, but it's source limitation and donor site morbidity makes some surgeon were looking for allograft or xenograft. There are some issues with allo- and xenograft about difficulty in corporation and rejection reaction. This study explores the immunogenicity of allograft and xenograft. Objective Aim of this study is to compare the immunogenicity between freeze-dried xenograft, freeze-dried allograft,hydroxyapatite xenograft, and demineralized bone matrix xenograft as a bone graft in bone defect of white rabbit femoral diaphysis. Materials and methods 30 White Rabbits New Zealand of 6-9 months age were assigned into 5 groups of 6 each (matched for age, sex and weight). Bone defect was made with diameter $2,5 \mathrm{~mm}$ until the medulla on femoral diaphysis. In the study group, bone defect was filled with xenograft freeze-dried cortical bovine, allograft freeze-dried cortical New Zealand White Rabbit, xenograft hydroxyapatite bovine, and xenograft demineralized bone matrix bovine. In control group, bone defect wasn't filled. Study and control group was sacrificed in first, second, and fourth weeks after implantation, 2 femurs for each week and each group. We evaluate immunoglobulin $G$ and level of IgG with immunohistochemistry, and histologically we evaluate fibrous tissue. Results The Immunoglobulin $G$ is elevate in control group and all study group but not significantly with $p=0,07$. There is asignificant difference of fibrous tissue between groups $(p<0.05)$ in first week, but on the second and fourth weeks found no significant difference $(p>0.05)$ between groups. Conclusion This study demonstrates that there's no significant elevation of Immunoglobulin $G$ in each group of bone graft. There's no significant difference in fibrous tissue formation level between xenograft and allograft in the fourth week.

\section{G OPEN ACCESS}

Keywords: freeze-dried xenograft, freeze-dried allograft, hydroxyapatite xenograft, demineralized bone matrix xenograft. 


\section{Introduction}

Bone defects often occur due to trauma, tumor, osteitis, implant loosening or corrective osteotomy and require operative therapy should be intervened by way of "bridging" bone defect.

Existing bone defects can be filled with bone graft where the bone graft is now a second transplantion, after a blood transfusion, as the most frequently performed. [3] However, management of bone defects is a challenge and requires a high cost with the use of bone graft will demand increasingly higher due to the fact of 4,000,000 operations that require a bone graft in the world each year [4], which in Indonesia alone would need allograft began to increase mainly to cover the bone defect in trauma cases with bone loss or bone tumor resection cases. Based on the data from Network Bank, in 2010 RSU Dr. Soetomo used as many as 62, in 2011 as many as 75, and in 2012 as many as 178. [5]

Autogenous bone graft becomes the gold standard because it has the ability of osteoinduction, osteoconduction, and osteogenesis and become the first choice of various experts Orthopaedic. But this autogenous bone graft has disadvantages including pain at the donor site and the potential occurrence of local complications such as hematoma, fractures and the limited availability. Due to the high morbidity and limited availability, it is considered to find a replacement that is the source of bone allograft [4]. Autogenous, cancellous bone is robustly osteogenic as it contains living osteogenic cells that can induce differentiation of host mesenchymal cells into osteoblasts and its structure can serve as an osteoconductive support for the ingrowth of sprouting capillaries, perivascular tissue, and osteoprogenitor cells from the recipient bed. However, it does not provide structural support. Autogenous, cortical bone provides structural support and is somewhat osteogenic, osteoinductive, and osteoconductive. However, revascularisation is slow and primarily the result of peripheral osteoclast resorption and vascular invasion of haversian canals. Therefore, the graft becomes weaker than normal bone, and large portions of dead cortical autograft may remain for long periods. [10]

Bone allografts have long been used as a natural substitute to cover the bone defect, as an alternative to autograft bone which availability is limited. [4] Advantage of the allograft is that the graft size can be adjusted. However it also has the disadvantages, such as the transmission of diseases, rejection reactions, graft-host junction non-union, graft resorption, fracture of allograft, and limitations of donor. $[6,9,11]$ Later on, xenograft was found, in which functionality is the same as allograft but it is feared 
that there will be rejections reactions, host-graft junction non-union, graft resorption and fracture of the allograft. [9]

Allograft rejection is a major concern. Bone transplantation stimulates skeletal repair and regeneration. Bone grafts have biological and mechanical functions. The biological activity of a graft includes osteogenesis (inherent activity), osteoinduction (activity of surrounding host tissues), and osteoconduction (ingrowth of host tissues). The mechanical environment affects bone remodelling. Skeletal graft incorporation is a multifaceted process in which multiple variables determine success or failure. The sequence includes haemorrhage, inflammation, revascularisation, substitution, and remodeling. $[10,15]$ Successful graft incorporation is defined as the ability of the graft and surrounding tissue to function and maintain mechanical integrity.

Allograft or xenograft can produce the rejection reaction and affect the bone healing. It became a consideration by the expert in selecting the use of bonegraft in orthopaedic. Based on these circumstances, authors conducted a study on the rejection reaction on freeze-dried bovine, freeze-dried allograft, hydroxyapatite bovine and demineralized bone matrix bovine to fill small bone defects in diaphysis of long bones.

\section{Material and Methods}

Randomized post-test only control group design was performed on 30 animals male New Zealand white rabbits weighing around $2,5-3,0 \mathrm{~kg}$. All rabbits are anesthetized with intramuscular ketamine (40 $\mathrm{mg} / \mathrm{kg}$ ) and xylazine (13 $\mathrm{mg} / \mathrm{kg}$ ). then do exposed the anterior side of $1 \mathrm{~cm}$ from the lateral epicondyle of the femur (diaphysis), then the incision periosteum, then made bone defects with a diameter of $2.5 \mathrm{~mm}$ and a depth of $2 \mathrm{~mm}$ (to penetrate the medulla). Then all the rabbits were randomized divided into fifteen groups. Three control groups then implanted graft in the treatment group implanted cortical bovine freeze dried in 3 groups, implanted cortical freezedried New Zealand White Rabbit in 3 groups, bovine hydroxyapatite implanted in the 3 groups, and implanted bovine demineralized bone matrix in three groups. After planting, the periosteum sutured with 2-o absorbable thread, sewn with yarn wound in a 2-o absorbable and skin wound sutured with 3-o absorbable thread and covered with waterproof plaster. Cephazolin given intramuscular injections during surgery until 3 days after surgery.

Immunohistochemical evaluation conducted at weeks 1, 2 and 4 in the control and treatment groups. Hematoxylin and eosin staining performed for histological evaluation and examined by light microscopy by two independent observers. Evaluation of 
rejection reactions by counting the number of immunoglobulin $\mathrm{G}$ in serological reactions with immunohistochemistry examination. The fibrous tissue width surrounding the graft by histopathological examination at $100 x$ and $400 x$ magnification also be evaluated.

\section{Result}

Figure 1 shows significant differences in the mean width of fibrous tissue between the groups in the first week in all groups. Width increase in fibrous tissue obtained during the second week with a peak in the second week and declined in the fourth week in all groups except for the bovine demineralized bone matrix. In the group of bovine demineralized bone matrix has decreased in the second week and declined again in the fourth week that can be seen on Figure 1. In the first week there is a significant difference between groups ( $p<0.05)$; on the second and fourth weeks found no significant difference ( $p>0.05$ ) between groups.

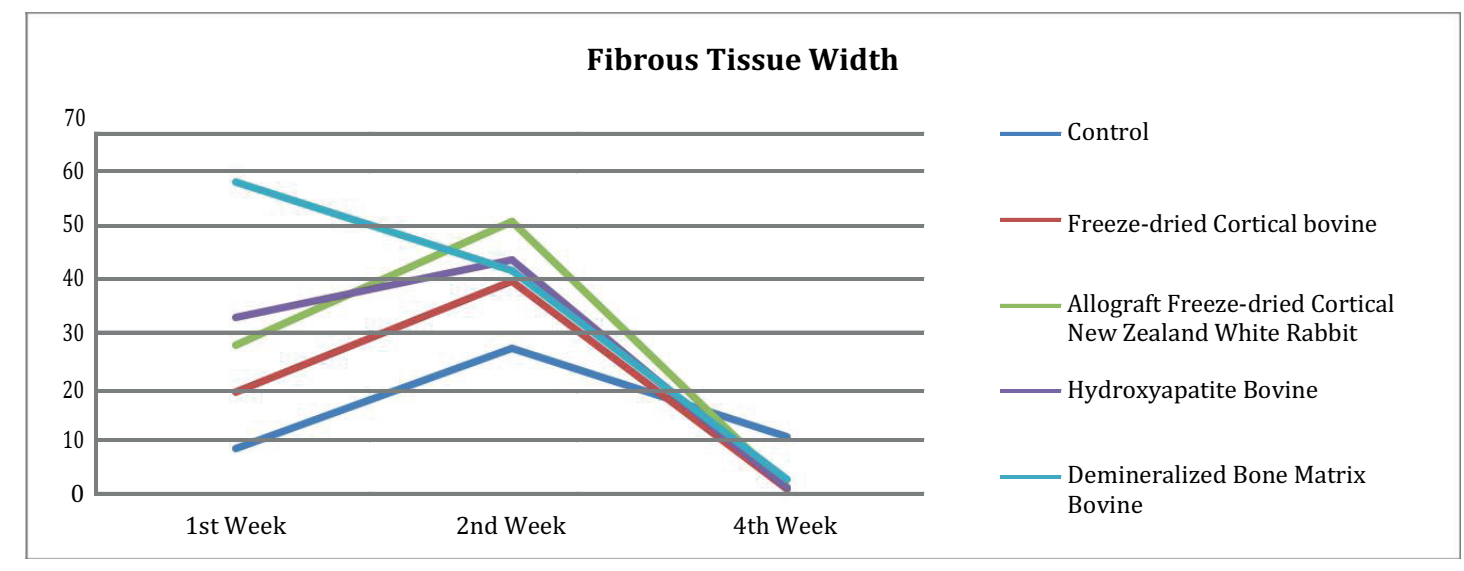

Figure 1: Evaluation of fibrous tissue width $(\mu)$.

In Figure 2 we found there were positive of Immunoglobulin $G$ in all groups but there were no significant differences between groups Immunoglobulin G well in the first week ( $p>0.05)$, the second week ( $p>0.05)$, and the fourth week ( $p>0.05)$.

In the control group, the formation of fibrous tissue already done in few area. In the second week there are elevation in width of woven bone accompanied by the formation of fibrous tissue, and both decrease in fourth week. Immunoglobulin already formed in the first week and decreased in the second week and increased in the fourth week but not significant.

In the freeze dried cortical bovine group, the first week was found formation of fibrous tissue which is increase in second week higher than the control group. 


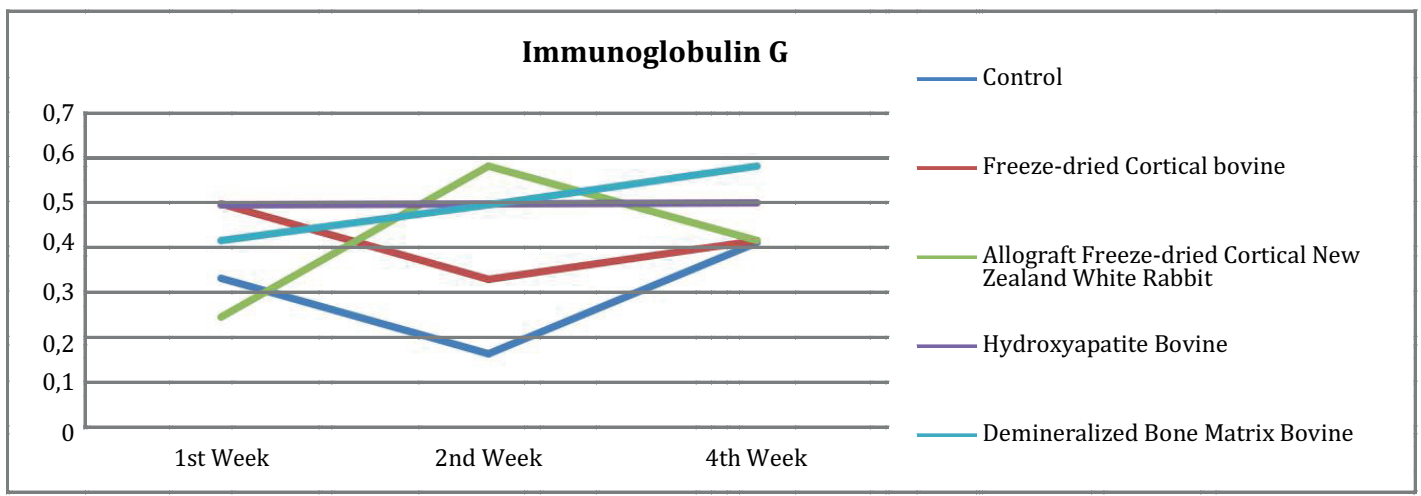

Figure 2

\begin{tabular}{|c|c|c|c|c|c|c|}
\hline \multirow[b]{2}{*}{ Variable } & \multicolumn{6}{|c|}{ Mean \pm SD } \\
\hline & Control & $\begin{array}{c}\text { Freeze Dried } \\
\text { Cortical } \\
\text { Bovine }\end{array}$ & $\begin{array}{c}\text { Freeze Dried } \\
\text { Cortical New } \\
\text { Zealand White } \\
\text { Rabbit }\end{array}$ & $\begin{array}{c}\text { Hydroxyapatite } \\
\text { Bovine }\end{array}$ & $\begin{array}{c}\text { Demineralized } \\
\text { Bone Matrix } \\
\text { Bovine }\end{array}$ & $P$ value \\
\hline 1st week lgG & $0,332 \pm 0,471$ & $0,497 \pm 0,429$ & $0,247 \pm 0,165$ & $0,495 \pm 0,195$ & $0,415 \pm 0,498$ & $\begin{array}{c}0,782 \\
(p>0,05)\end{array}$ \\
\hline 2nd week IوG & $0,165 \pm 0,190$ & $0,330 \pm 0,269$ & $0,580 \pm 0,320$ & $0,497 \pm 0,335$ & $0,495 \pm 0,190$ & $\begin{array}{c}0,210 \\
(p>0,05)\end{array}$ \\
\hline 4th week IgG & $0,412 \pm 0,165$ & $0,415 \pm 0,419$ & $0,415 \pm 0,629$ & $0,500 \pm 0,577$ & $0,580 \pm 0,320$ & $\begin{array}{c}0,905 \\
(p>0,05)\end{array}$ \\
\hline
\end{tabular}

\begin{tabular}{|c|c|c|c|c|c|c|}
\hline \multirow[b]{2}{*}{ Variable } & \multicolumn{6}{|c|}{ Mean \pm SD } \\
\hline & Control & $\begin{array}{l}\text { Freeze Dried } \\
\text { Cortical } \\
\text { Bovine }\end{array}$ & $\begin{array}{c}\text { Freeze Dried } \\
\text { Cortical New } \\
\text { Zealand White } \\
\text { Rabbit }\end{array}$ & $\begin{array}{c}\text { Hydroxyapatite } \\
\text { Bovine }\end{array}$ & $\begin{array}{c}\text { Demineralized } \\
\text { Bone Matrix } \\
\text { Bovine }\end{array}$ & $P$ value \\
\hline $\begin{array}{l}\text { 1st week } \\
\text { Fibrous } \\
\text { Tissue } \\
\text { width }\end{array}$ & $8,122 \pm 3,751$ & $18,687 \pm 3,031$ & $27,290 \pm 3,873$ & $32,287 \pm 2,085$ & $57,530 \pm 11,424$ & $\begin{array}{c}0,001 \\
(p<0,05) \\
\text { (Kruskal } \\
\text { Wallis) }\end{array}$ \\
\hline $\begin{array}{l}\text { 2nd week } \\
\text { Fibrous } \\
\text { Tissue } \\
\text { width }\end{array}$ & $26,662 \pm 2,452$ & $39,125 \pm 11,820$ & $50,192 \pm 5,250$ & $43,065 \pm 9,077$ & $41,070 \pm 12,666$ & $\begin{array}{c}0,032 \\
(p<0,05) \\
\text { (One } \\
\text { Way } \\
\text { Anova) }\end{array}$ \\
\hline $\begin{array}{l}\text { 4th week } \\
\text { Fibrous } \\
\text { Tissue } \\
\text { width }\end{array}$ & $10,205 \pm 8,206$ & $0,610 \pm 0,790$ & $1,037 \pm 0,415$ & $0,830 \pm 0,677$ & $2,432 \pm 2,214$ & $\begin{array}{c}0,019 \\
(p<0,05) \\
\text { (Kruskal } \\
\text { Wallis) }\end{array}$ \\
\hline
\end{tabular}

Immunoglobulin already formed in the first week and decreased in the second week and increased in the fourth week but not significant.

In the group of freeze dried cortical allograft New Zealand white rabbit, in the first week there were formation of fibrous tissue higher than control and freeze dried cortical bovine group. In the second week the formation fibrous tissue were increased and also higher than control and freeze dried cortical bovine group. In the fourth week 
there were significant decreased of fibrous tissue same with the freeze dried cortical bovine group. Immunoglobulin were formed from the first week and increased at second week but not significant, and the decreased in the fourth week.

In the group of bovine hydroxyapatite at figure, in the first week there were formation of fibrous tissue which were increased higher than control and freeze dried cortical bovine group in second week. In the fourth week there were significant decreased of fibrous same with the freeze dried cortical bovine group and allograft freeze dried cortical New Zealand white rabbit group. Immunoglobulin were formed from the first week and increased at second week but not significant, and the decreased in the fourth week. This is similar to freeze dried cortical allograft group of New Zealand white rabbit.

Demineralized bone matrix group, during the first week there were large width fibrous tissue which is highest in the first week and decreased of fibrous tissue in second week. In fourth week fibrous tissue were decreased. Immunoglobulin was formed from the first week and increase at second and fourth week but not significant.

In control group, in the first week, there were few number of woven bone and fibrous tissue. In the fourth week there were decreased of fibrous tissue and woven bone but still with lot of porous in woven bone and clear margin between the woven bone and the native bone that is seen in Figure 3.
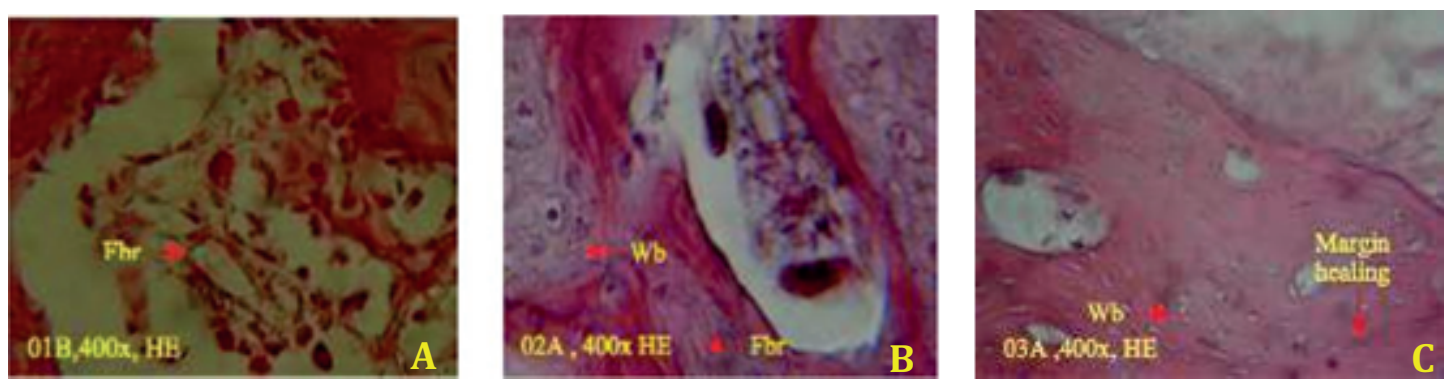

Figure 3: Histology of control group (A) the first week; $(B)$ the second week; (C) fourth week.

In freeze-dried Bovine cortical group, almost same with the control group, at Figure $4 \mathrm{~A}$ in the first week, we see a few number of woven bone and fibrous tissue. In the second week, there were increased of fibrous tissue and woven bone as seen at Figure $4 \mathrm{~B}$, less than the control group. In the fourth week, in Figure $4 \mathrm{C}$, the fibrous tissue and woven bone were decreased but we found lot of porous in woven bone with clear margin between the woven bone and the native bone.

In Freeze-dried allograft cortical New Zealand White Rabbit group, almost same with the control group, at Figure $5 \mathrm{~A}$ in the first week, we see a lot of woven bone and fibrous tissue, higher than the control group. In the second week, as seen in Figure 

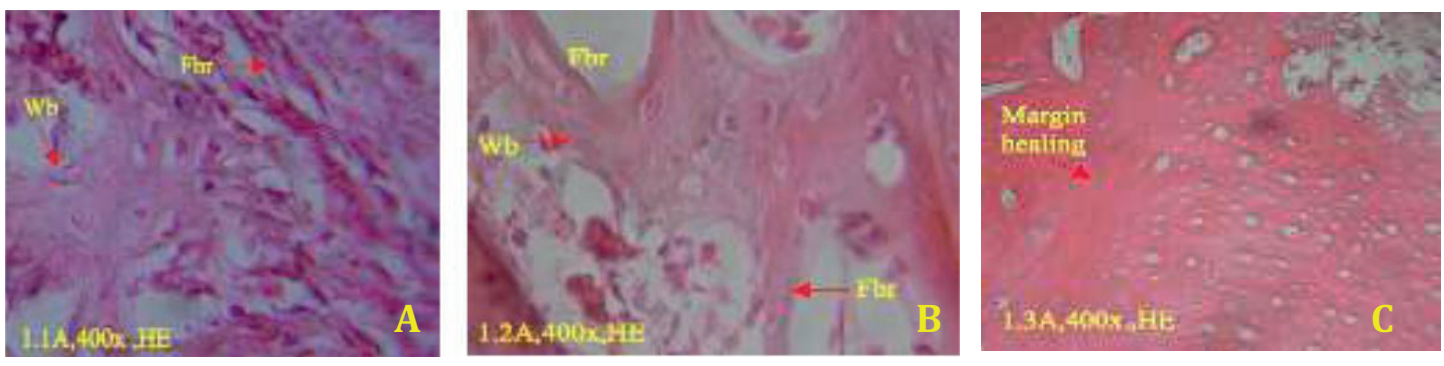

Figure 4: Histology of Freeze-dried Bovine cortical group (A) the first week; (B) the second week; (C) fourth week.

$5 \mathrm{~B}$, increased of fibrous tissue and woven bone significantly, more than the control group. In the fourth week, in Figure $5 \mathrm{C}$, decreased of fibrous tissue and woven bone. Eventhough, we still found clear margin between the woven bone and the native bone, with larger porous in woven bone.

In hydroxyapatite Bovine group, almost the same with the control group. In the first week, at Figure 6A, we found large number of woven bone and fibrous tissue. In the second week, as seen in Figure $6 \mathrm{~B}$ and $11 \mathrm{C}$, we found increased of fibrous tissue and woven bone. In the fourth week, in Figure 6D, fibrous tissue and woven bone were decreased. Eventhough, we still can see larger porous of woven bone compare with the native bone, and clear margin between woven bone and native bone, with larger porous in woven bone.
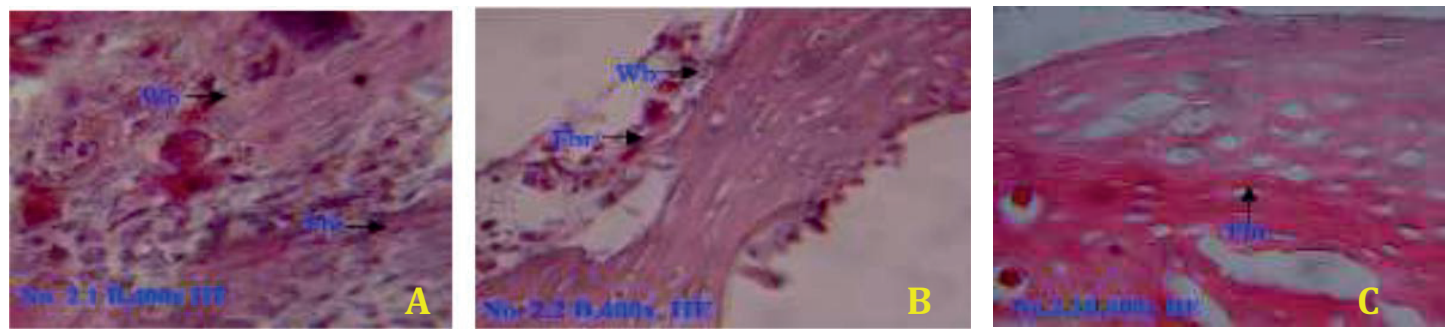

Figure 5: Histology of Freeze-dried allograft cortical New Zealand White Rabbit group (A) the first week; (B) the second week; (C) fourth week.

In demineralized bone matrix Bovine group, there are significant different with other group, including the control group. In the first week, at Figure $7 \mathrm{~A}$, we found lot of woven bone and fibrous tissue. In the second week there were decreased of fibrous tissue and woven bone due to process of calcification as seen in Figure $7 \mathrm{~B}$. In the fourth week, the fibrous tissue and woven bone were decreased with woven bone that already calcified as shown in Figure $7 \mathrm{C}$. This is proven with unclear margin between woven bone and native bone. We hardly different the margin between the woven bone the native bone.

In Figure 8, there was difference in bone healing between demineralized bone matrix bovine group with other groups in the fourth week in which the group of 

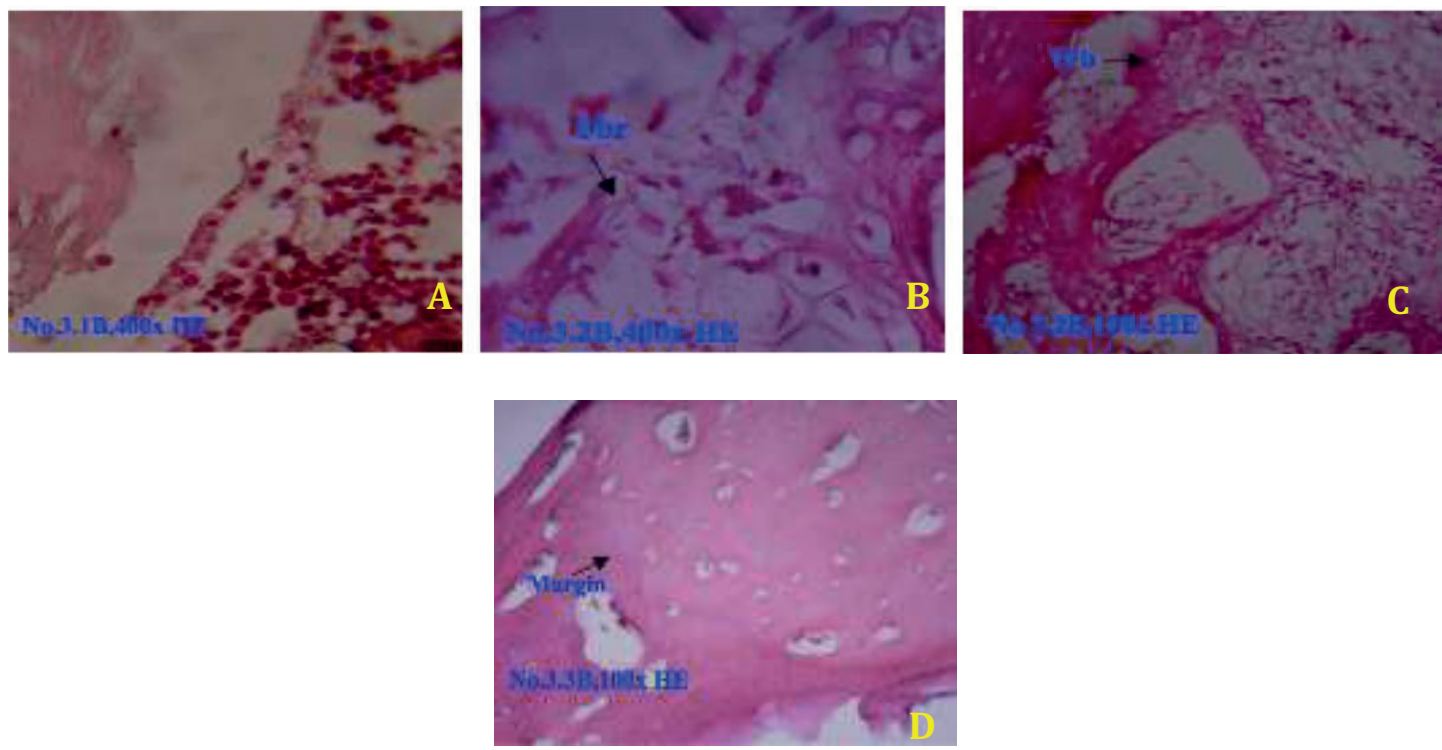

Figure 6: Histology of Hydroxyapatite Bovine group (A) the first week; (B) and (C) the second week; (D) fourth week.
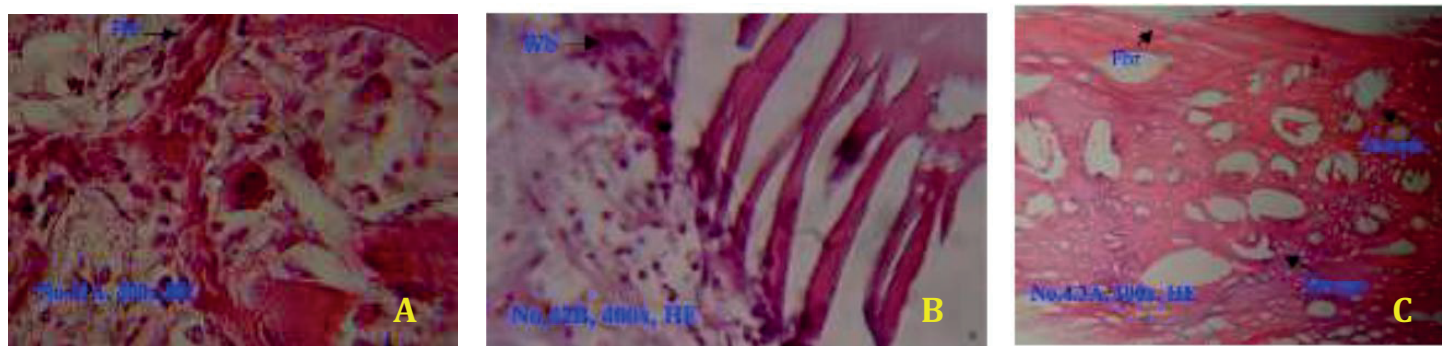

Figure 7: Histology of Hydroxyapatite Bovine group (A) the first week; (B) the second week; (C) fourth week.

demineralized bone matrix bovine Figure 8E, healing (arrow) already resembles the native bone, such as bone at the margins, with smaller and less porous, and fibrous tissue that is not as thick as the other group. While in other groups, Figure 8A control group, Figure 8B freeze-dried Bovine cortical group, Figure 8C freeze-dried allograft cortical New Zealand White Rabbit group, and Figure 8D hydroxyapatite Bovine group, we can clearly seen the margin between the healing process with the native bone.

Figure 9 shows the reaction of Immunoglobulin $\mathrm{G}$ in each group where there is no difference between the groups in the first week, second week, and the fourth week, that are seen in Figure $9 \mathrm{~A}$ control group, Figure $9 \mathrm{~B}$ freeze-dried Bovine cortical group, Figure $9 C$ freeze-dried allograft cortical New Zealand White Rabbit group, Figure 9D hydroxyapatite Bovine group, and Figure gE demineralized bone matrix Bovine group at fourth week. 

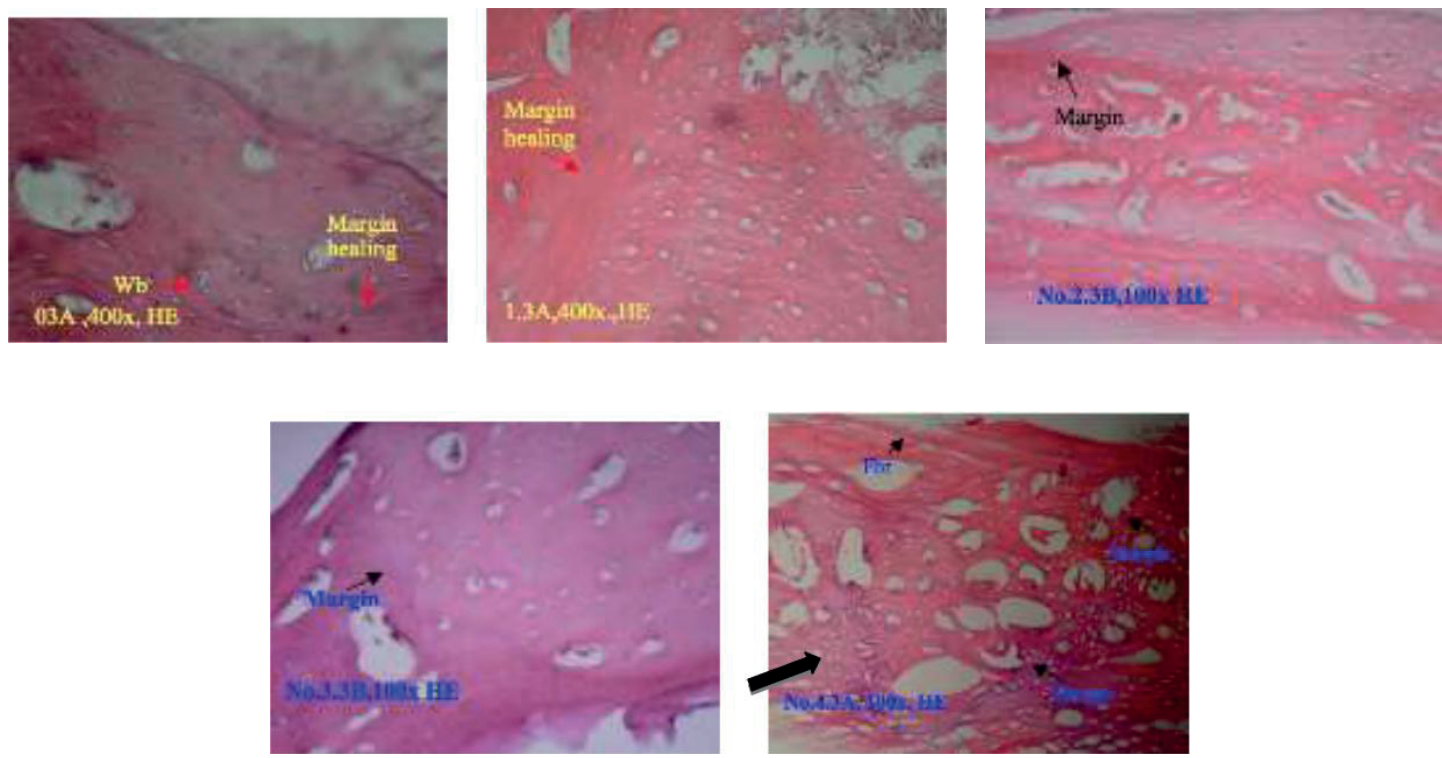

Figure 8: Histology at week four (A) control group; (B) Freeze-dried Bovine cortical group; (C) Freeze-dried allograft cortical New Zealand White Rabbit group; (D) Hydroxyapatite Bovine group; (E) Demineralized bone matrix Bovine group.
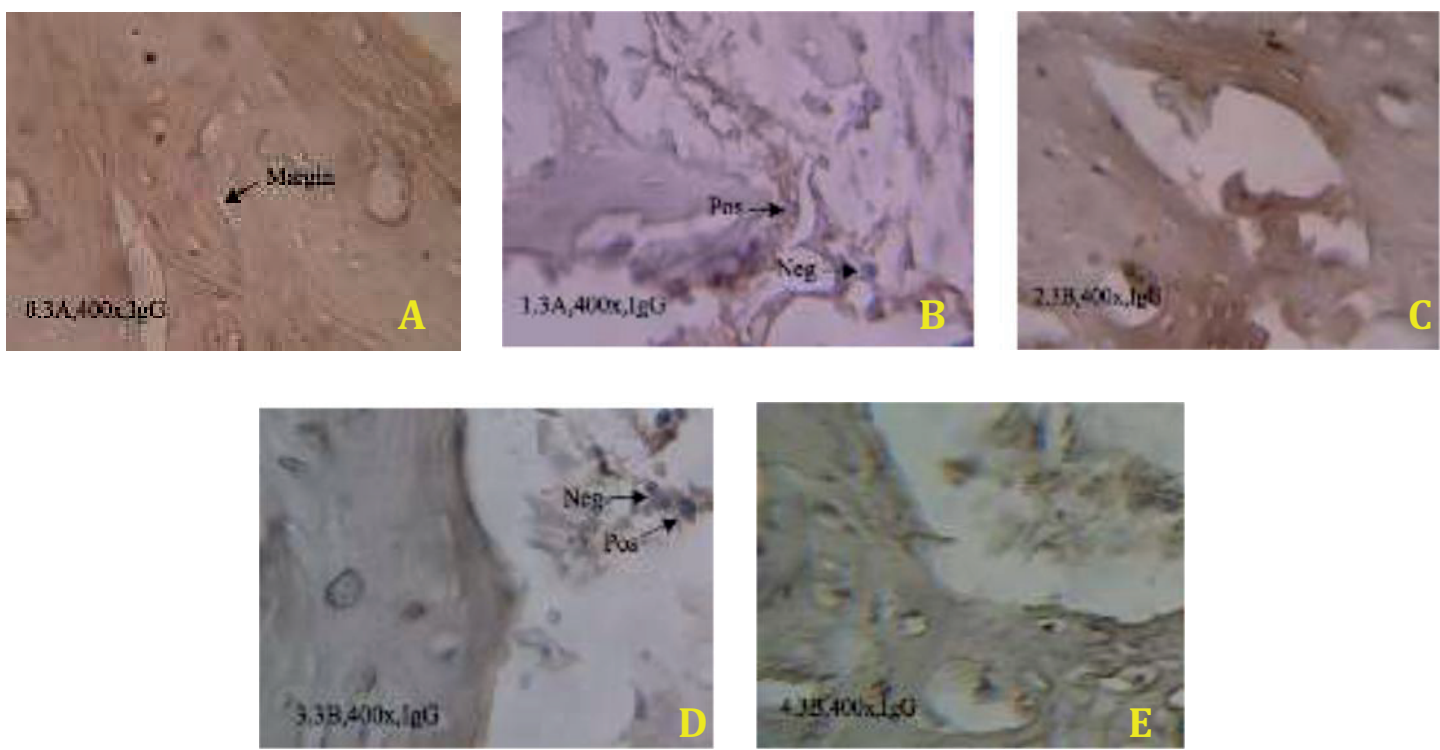

Figure 9: Immunology at week four (A) control group; (B) Freeze-dried Bovine cortical group; (C) Freeze-dried allograft cortical New Zealand White Rabbit group; (D) Hydroxyapatite Bovine group; (E) Demineralized bone matrix Bovine group.

\section{Discussion}

Ideal bonegraft or substitute should be a material that is biologically inert, easily adaptable to the site in terms of shape and size and replaceable by the host bone. Here in this study we found the immune reaction in Demineralized Bone Matrix Bovine, Hydroxyapatite Bovine, freeze-dried allograft group of New Zealand White Rabbit, groups Bovine cortical freeze-dried, and the control group. We obtained an increase of 
Immunoglobulin $\mathrm{G}$ in all groups, even in the control group indicating that immunological reactions will still exist.

Immunoglobulin were formed higher in Demineralized Bone Matrix Bovine group in the first week then increased in the second and fourth week. Immunoglobulin were formed lowest in freeze-dried allograft group from the first week, with an increased in second week, and decreased in the fourth week. Evaluation of Immunoglobulin G was no significant difference between groups indicating that immunological reactions will still exist but there is no significant difference. This is not in accordance with previous literature stating that immunulogi response that occurs higher in the xenograft compared to the allograft group [19]. Immunological reactions can be minimized with good processing techniques. In addition to the previously available literature immunological reactions on hydroxyapatite [21] can be ignored, according to the results of this study.

Ideal bonegraft when implanted into tissue is progressively resorbed by osteoclasts while at the same time, ostcoblasts using the freed calcium ions to produce new bone. In this study, woven bone is formed in the first week and will increase up to the second week in all groups except in the group of Demineralized Bone Matrix Bovine where in this group of woven bone that formed the highest in the first week and the second week has been a decline of woven bone due to calcification occurs from woven bone. This indicates that the process of callus formation will occur from the first week and a maximum in the second week, and will occur calcification in the second week until healing occurs.

From this study, the bone healing process in group Demineralized Bone Matrix Bovine faster than the group Hydroxyapatite Bovine, freeze-dried allograft group of New Zealand White Rabbit, groups Bovine cortical freeze-dried, and the control group that can be seen from the woven bone that already elevate in first week and calcified and second week. This study fits with previous research which states that bone healing in the DBM is better than in HA [24].

\section{Conclusion}

There's no significant elevation of Immunoglobulin $G$ in each group of bone graft. There's no significant differences in mean bone healing process between xenograft and allograft in the fourth week. Bone healing in bovine xenograft demineralized bone matrix is faster than the other groups. 


\section{References}

[1] Dimitriou R. Bone regeneration: current concepts and future directions. Dimitriou et al. BMC Medicine. 2011; 9(66): p. 3-10.

[2] Heo SY. Biomechanical assessment of freeze-dried allograft cortical bone plate graft in canine bone defect model. Veterinarni Medicina. 2009; 54: p. 183-190.

[3] Irene Mencía Castaño CMCGPDFJO. Next generation bone tissue engineering: non-viral miR-133a inhibition using collagen-nanohydroxyapatite scaffolds rapidly enhances osteogenesis. Scientific report. 2016 June 14; 6: p. 1-10.

[4] Brydone AS. Bone grafting, orthopaedics biomaterial, and the clinical need for bone engineering. J Engineering in Medicine. 2010 Agustus 12; 224: p. 1329-1343.

[5] Munthe RV. Evaluasi hasil rekonstruksi defek tulang besar dengan massive bone allograft. Retrospective Study. Surabaya: University of Airlangga, Orthopaedy and Traumatology; 2013.

[6] Chad M. Autogenous Bone Graft: Donor Sites and Techniques. J Bone Joint Surg Am. 2011; 93: p. 2227-36.

[7] Greenwald AS. Bone-Graft Substitutes: Facts, Fictions \& Aplications. Bone Joint Surg Am. 2001; 83: p. 98-103.

[8] Nandi SK. Orthopaedic applications bone graft \& graft substitutes: a riview. Indian J Med Res. 2010 July; 132: p. 15-30.

[9] J.P. Gleeson NAPaFJO. Addition of Hydroxyapatite Improves Stiffness Interconnectivity and Osteogenic Potential of a Highly Porous Collagen-Based Scaffold for Bone Tissue Regeneration. European Cells and Materials. 2010; 20: p. 218-230.

[10] Hamid Shegarfi OR. Review Article: Bone transplantation and immune response. Journal of Orthopaedic Surgery. 2009 August; 17(2): p. 206-211.

[11] Hung NN. Basic Knowledge of Bone Grafting. In Zorzi A. Bone Grafting. Croatia: InTech, Chapters; 2012. p. 11-38.

[12] Cornu 0. Influence of Freeze-Drying and Irradiation on Mechanical Properties of Human Cancellous Bone: Application to Impaction Bone Grafting. In Zorzi A. Bone Grafting. Croatia: InTech; 2012. p. 41-58.

[13] Kinney RC. Demineralized Bone Matrix for Fracture Healing: Fact or Fiction?. J Orthop Trauma. 2010 March; 24(3): p. 52-55.

[14] Walsh MC KNYJSJa. Osteoimmunology: Interplay Between the Immune System and Bone Metabolism. Annu. Rev. Immuno. 2006 October 12; I(24): p. 33-63.

[15] Heiple KG CSHC. A comparative study of the healing process following different types of bone transplantation. J Bone Joint Surg Am. 1963; 45: p. 1593-616. 
[16] Afzali B LRHFM. Allorecognition and the Alloresponse: Clinical Implications. Tissue Antigens. 2007 March;(69): p. 545-56.

[17] Reikeras O SHNCRFRB. Impact of MHC mismatch and freezing on bone graft incorporation: an experimental study in rats. J Orthop Res. 2008; 26: p. 925-31.

[18] Ludwig SC BS. Osteoinductive bone graft substitutes for spinal fusion: a basic science summary. Orthop Clin North Am. 1999; 30: p. 635-45.

[19] David Easter. Practical Considerations for Biologic Scaffolds. In Jacobsen G, editor. Allograft vs.Xenograft. San Diego: University of California; 2009. p. 2-13.

[20] Aliabadi A. Evaluation of the effects of bovine demineralized bone matrix and coralline hydroxyapatite on radial fracture healing in rabbit. Journal of Cell and Animal Biology. 2012 April 15; 6(7): p. 109-114.

[21] Dumitrescu AL. Bone Grafts and Bone Graft Substitutes in Periodontal Therapy. In Dumitrescu AL, editor. Chemicals in Surgical Periodontal Therapy. Berlin: Springer; 2011. p. 73-144.

[22] John Street ea. Vascular endothelial growth factor stimulates bone repair by promoting angiogenesis and bone turnover. Proceedings of the National Academy of Sciences of the United States of America. 2002 July 23; 99(15): p. 9656-9661.

[23] Brandon Beamer B\&CHMM\&JLM. Vascular Endothelial Growth Factor: An Essential Component of Angiogenesis and Fracture Healing. Hospital for Special Surgery Journal. 2010; 6: p. 85-94.

[24] Santic V. Treatment of Tibial Bone Defect with Rotational Vascular Periosteal Graft in Rabbits. Coll. Antropol. 2008 February 8; 33(1): p. 43-50.

[25] Bowen JA MJGJTH. Comparison of decalcified freeze-dried bone allograft and porous particulate hydroxyapatite in human periodontal osseous defects. Journal Periodontal. 1989 December; 6o(12): p. 647-654. 